\title{
Variations in dissolved organic carbon concentrations across peatland hillslopes
}

\author{
I.M. Boothroyd ${ }^{\mathrm{a}, *}$, F. Worrall ${ }^{\mathrm{a}}$, T.E.H. Allott ${ }^{\mathrm{b}}$ \\ ${ }^{a}$ Department of Earth Sciences, Durham University, Science Labs, Durham DH1 3LE, UK \\ ${ }^{\mathrm{b}}$ Department of Geography, School of Environment, Education and Development, The University of Manchester, Manchester M13 9PL, UK
}

\section{A R T I C L E I N F O}

\section{Article history:}

Received 31 January 2015

Received in revised form 25 August 2015

Accepted 3 October 2015

Available online 8 October 2015

This manuscript was handled by Laurent

Charlet, Editor-in-Chief, with the assistance

of Ewen James Silvester, Associate Editor

\section{Keywords:}

Hillslope position

Peat

DOC

Carbon cycle

\begin{abstract}
S U M M A R Y
Peatlands are important terrestrial carbon stores and dissolved organic carbon (DOC) is one of the most important contributors to carbon budgets in peatland systems. Many studies have investigated factors affecting DOC concentration in peatland systems, yet hillslope position has been thus far overlooked as a variable that could influence DOC cycling. This study investigates the importance of hillslope position with regard to DOC cycling. Two upland peat hillslopes were studied in the Peak District, UK, to determine what impact, if any, hillslope position had upon DOC concentration. Hillslope position was found to be a significant factor affecting variation in soil pore water DOC concentration, with bottom-slope positions having significantly lower DOC concentrations than up-slope because of dilution of DOC as water moves down-slope and is flushed out of the system via lateral throughflow. Water table drawdown on steeper mid-slopes increased DOC concentrations through increased DOC production and extended residence times allowing a build-up of humic-rich DOC compounds. Hillslope position did not significantly affect DOC concentrations in surface runoff water because of the dilution of near-surface soil pore water by precipitation inputs, while stream water had similar water chemistry properties to soil pore water under low-flow conditions.
\end{abstract}

(c) 2015 Elsevier B.V. All rights reserved.

\section{Introduction}

Peatlands are one of the most important global terrestrial carbon (C) stores due to the accumulation of organic material over time in these ecosystems. An estimated $446 \mathrm{Gt} \mathrm{C}$ is stored across a global peatland area of $3813553 \mathrm{~km}^{2}$ (Joosten, 2009) and the United Kingdom (UK) is estimated to store $1.745 \mathrm{GtC}$ in peat soils (Joosten, 2009). The UK holds $14.8 \%$ of Europe's soils with an organic C content of greater than 25\% (Montanarella et al., 2006). In the UK, blanket bogs represent the largest proportion of the peatland area, an estimated 85-92\% (Clark et al., 2010b; Lindsay, 1995) and are typically found in upland environments, where cooler temperatures and high levels of rainfall favour formation of peat soils.

Dissolved organic carbon (DOC) is a large component of peatland $C$ budgets and can influence the size of the $C$ sink or source. Studies from ombrotrophic systems in North America and Europe suggest DOC represents $17-37 \%$ of annual net ecosystem exchange (Dinsmore et al., 2010; Koehler et al., 2011; Roulet et al., 2007; Worrall et al., 2009a, 2003) and up to $54.3 \%$ of total aquatic C losses

\footnotetext{
* Corresponding author. Tel.: +44 (0)191 334 2295; fax: +44 (0)191 3342301.

E-mail address: i.m.boothroyd@durham.ac.uk (I.M. Boothroyd).
}

(Dinsmore et al., 2013). An increase in DOC concentrations has been observed for many UK upland streams in recent decades: a $65 \%$ increase in DOC concentration was observed over a 12 year period (Freeman et al., 2001a), whilst Worrall et al. (2004), stated there was a 77\% increase in DOC across 198 catchments over a period of between 8 and 42 years. It is therefore important to develop as thorough an understanding as possible of the processes that drive the production and transport of peatland DOC.

The processes driving DOC export from peatlands are numerous, with multiple biotic and abiotic controls affecting DOC concentrations and the flux of DOC from peatland catchments. Freeman et al. (2001b) and Fenner and Freeman (2011) argued that water table drawdown in peatlands would provide aerobic conditions to allow phenol oxidase to reduce the concentration of phenolic compounds, thus leading to greater hydrolase enzyme activity and ultimately higher levels of DOC production that would continue even in anaerobic conditions, i.e. once water tables have risen. Alternatively, water table drawdown may cause oxidation of sulphur to sulphate which in turn acts to suppress the solubility of DOC (Clark et al., 2005; Daniels et al., 2008). Increased $\mathrm{SO}_{4}^{2-}$ content in catchments with a high density of gullying has resulted in lower concentrations of DOC compared to catchments with a low density of gullying (Daniels et al., 2008). Declining atmospheric 
deposition of sulphate has been linked to increased solubility of DOC in peatlands (Monteith et al., 2007; Evans et al., 2012). Rising temperatures have been shown to enhance DOC concentration (Clark et al., 2005; Freeman et al., 2001a) and is linked to increased biological activity (Dinsmore et al., 2013). The sensitivity of DOC production to temperature is affected by the water level within the soil (Clark et al., 2009). Moreover, increasing evapotranspiration with climate change may negate and perhaps lower DOC export despite increasing temperatures (Pastor et al., 2003).

Land management can also affect DOC production and transport. Dissolved organic carbon export was shown to be significant from urban and grazed land on mineral and organo-mineral soils, but not arable land (Worrall et al., 2012), while moorland burning has been suggested to affect DOC concentration (Yallop and Clutterbuck, 2009) and composition (Clutterbuck and Yallop, 2010) but may only be evident over short timescales (Clay et al., 2009) and may not be apparent over long time periods if the degree of burning has not changed over time (Chapman et al., 2012). Peat drainage has also been shown to influence the production and export of DOC, with enhanced drainage increasing DOC production and therefore DOC concentration through increased decomposition of peat in the greater aerobic zone; therefore drain blocking has the effect of reducing aerobic decomposition of peat and production of DOC, thus lowering DOC concentration (Höll et al., 2009; Turner et al., 2013; Wallage et al., 2006). Others have argued that management intervention techniques do not decrease production but alter the yield of DOC (Gibson et al., 2009), while DOC concentrations can increase post blocking due to accumulation of dissolved organic matter at depth (Glatzel et al., 2003).

If it is possible that features such as drainage ditches can affect the production and cycling of DOC then one aspect of the landscape that has been overlooked with regards to DOC dynamics in peatland systems is the potential impact of hillslope position. Hillslope position could have an important influence upon DOC in peatlands for a number of reasons. Hillslope position is a control upon water table depth (WTD) and can affect flowpath and runoff generation (Holden, 2009; Holden and Burt, 2003), meaning that hillslope position could influence the transport of DOC from shedding to accumulating areas at the base of the hillslope. Preferential flow routes could also affect the transfer of $C$ across the hillslope. Soil pipe networks, which have been shown to vary with hillslope position (Holden, 2005a), act as conduits for C export, including DOC (Holden et al., 2012), which can be dominated by near-surface, young, C sources (Billett et al., 2012). Conversely, runoff generation and the style of runoff event can be controlled by such variables as the nature of the rainfall, i.e. a factor independent of hillslope position (Heppell et al., 2002). Hillslope position will be an important feature of blanket bogs, yet it may have been neglected previously due to the study of raised bogs.

It has been argued that understanding of the effect water movement has upon DOC retention and release is limited (Holden, 2005b; Limpens et al., 2008) and topographic variation could be amongst the unknown controls (Clark et al., 2010a). As such, investigating the role of hillslope position will improve the understanding of $\mathrm{C}$ cycling in peatlands. Furthermore, understanding of DOC dynamics has been improved by assessing the role of hillslope for non-peat soils (Creed et al., 2013; McGlynn and McDonnell, 2003), with changes in DOC concentration between upland hillslope areas and flatter riparian zones observed (Mei et al., 2012; Morel et al., 2009). Furthermore, hillslope position can be quantified and incorporated in C budget models, just as altitude in Worrall et al. (2009b). Slope position also influences other biogeochemical cycles, such as the transport of nitrates (Castellano et al., 2013). However, little work has been conducted to assess the exact role of hillslope in peatland catchments, which could be expected to behave differently.
This study will assess the role of hillslope position on DOC concentrations in soil pore water and surface runoff water in peatland catchments across 24 months and determine how water chemistry varies along the hillslope and relate this to changes in flowpath and compositional mixing.

\section{Materials and methods}

\subsection{Study sites}

The study was conducted across two hillslopes, Featherbed Moss and Alport Low (Fig. 1) in the Peak District National Park, Derbyshire. Featherbed Moss is a round ridge connecting Kinder Scout and Bleaklow that acts as a watershed separating the River Ashop and Shelf Brook, and is underlain by soft Pendle or Shale Grits (Tallis, 1973). Featherbed Moss is Eriophorum spp. dominated and has a northerly aspect (Table 1 ). Peat depth on Featherbed Moss was between 1.60 and $2.79 \mathrm{~m}$. Alport Low is steeper than Featherbed Moss, with slope angles exceeding $10^{\circ}$ from horizontal and has suffered from more extensive erosion than Featherbed Moss. Erosion of peat at Alport Low has led to the formation of gullies, with two distinct types formed dependent upon topography. Type I gully erosion (Bower, 1961) occurs on areas with low slope angles of $<5^{\circ}$ where erosion of peat is extensive, leading to a network of branching and dissecting gullies that are dendritic in nature. Type II gully erosion occurs on steeper ground and typically takes the form of linear, unbranched gullies that run straight down the hillslope. Alport Low is underlain by the Millstone Grit Series, with thin periglacial deposits overlying the bedrock. Alport Low has a mixture of vegetation, with Eriophorum spp., Vaccinium myrtillus and non-Sphagnum mosses, owing to greater variation in slope angle and the presence of erosional gullies. Alport Low has a southerly aspect with Eriophorum spp. dominating flatter areas on the top and bottom of the hillslope, while $V$. myrtillus and non-Sphagnum mosses were present on the mid-slopes, particularly in areas with hummocky topography (Fig. 1). Peat depth varied between 1.23 and $2.96 \mathrm{~m}$ on Alport Low in Experiment 1 (Section 2.2) and $0.82-2.73 \mathrm{~m}$ in Experiment 2. The deepest deposits were at the bottom of the hillslope.

\subsection{Experimental design}

Two studies were conducted across two years: June 2010-June 2011, hereafter called Experiment 1; and September 2011-August 2012, hereafter called Experiment 2. Experiment 1 was conducted on both Featherbed Moss and Alport Low, with slope position divided into top-slope, mid-slope and bottom-slope. The midslope was further subdivided into upper and lower mid-slope sections so as to increase monitoring on the slope and capture a better resolution of slope and altitudinal variation (Table 1). Each slope position had six study plots, which were subdivided into two groups of three. This created a further sub-slope category nested within slope position to capture better spatial resolution within the slope positions, given the heterogeneous nature of peatlands and the variation in conditions at a plot scale. The sub-slope positions were separated with an arbitrary designation of 'A' and ' $B$ '. On Alport Low, the top-slope and bottom-slope had two further subslope designations of ' $C$ ' and 'D' to account for extra plots distinguishing Eriophorum spp. and hummock plots. Percentage of Eriophorum spp. dominance, recorded from a vegetation survey in August 2011, was incorporated as a covariate in the experimental design. On the Alport Low mid-slope the sub-slope plots were separated onto different interfluves and each sub-slope plot was more than two metres away from either side of a gully to avoid possible 

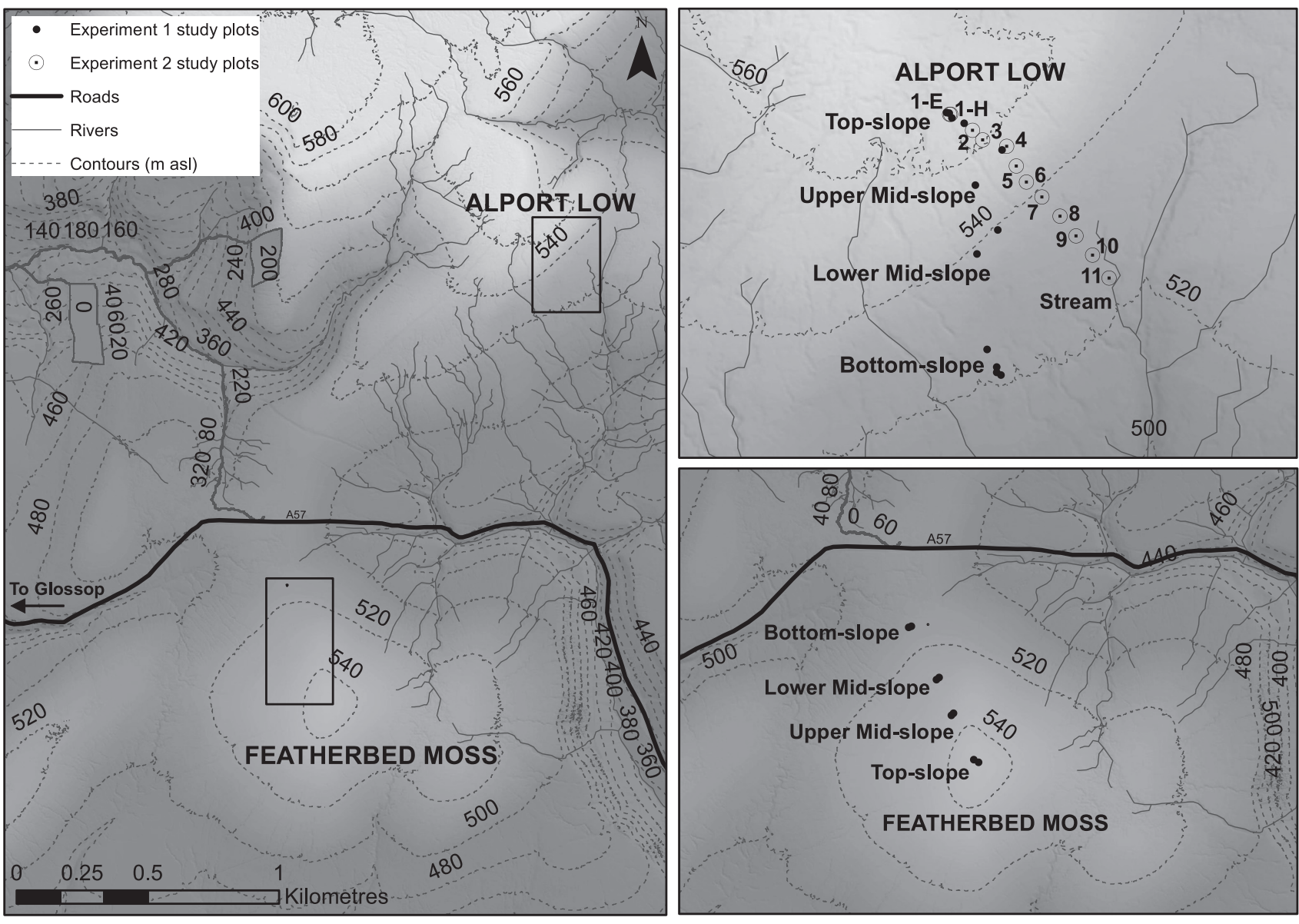

Fig. 1. Map of study sites in Peak District, Derbyshire, UK. Boxes in left panel show extent of study plots in right panels.

Table 1

Experiment 1 slope position details by study site. Eriophorum dominance numbers refer to plots $1 ; 2 ; 3$ or $4 ; 5 ; 6$.

\begin{tabular}{|c|c|c|c|c|c|c|c|c|c|}
\hline Site & Slope position & $X$ & $Y$ & Plot & Eriophorum dominance (\%) & Altitude (m) & Aspect $\left({ }^{\circ}\right)$ & Slope $\left({ }^{\circ}\right)$ & Wetness index \\
\hline \multirow[t]{8}{*}{ Featherbed moss } & \multirow{2}{*}{ Top-slope } & 409045 & 392108 & $1-3$ & $96 ; 96 ; 100$ & 543.7 & 152.2 & 1.0 & 6.5 \\
\hline & & 409064 & 392097 & $4-6$ & $88 ; 88 ; 96$ & 543.7 & 51.8 & 1.1 & 5.6 \\
\hline & \multirow[t]{2}{*}{ Upper Mid-slope } & 408960 & 392276 & $1-3$ & $100 ; 100 ; 84$ & 535.0 & 294.6 & 4.2 & 6.9 \\
\hline & & 408969 & 392285 & $4-6$ & $100 ; 92 ; 100$ & 535.1 & 302.3 & 3.8 & 7.2 \\
\hline & \multirow{2}{*}{ Lower Mid-slope } & 408903 & 392413 & $1-3$ & $96 ; 88 ; 100$ & 525.8 & 331.0 & 3.4 & 7.6 \\
\hline & & 408914 & 392420 & $4-6$ & $100 ; 28 ; 96$ & 525.9 & 326.6 & 3.6 & 7.9 \\
\hline & \multirow[t]{2}{*}{ Bottom-slope } & 408797 & 392611 & $1-3$ & $100 ; 72 ; 100$ & 514.9 & 291.5 & 3.8 & 7.7 \\
\hline & & 408808 & 392616 & $4-6$ & $96 ; 100 ; 100$ & 515.4 & 303.5 & 3.3 & 7.3 \\
\hline \multirow[t]{12}{*}{ Alport low } & \multirow[t]{2}{*}{ Top-slope (hummock) } & 410027 & 394271 & $1-3$ & $48 ; 36 ; 68$ & 564.1 & 151.0 & 4.1 & 4.0 \\
\hline & & 410031 & 394270 & $4-6$ & $12 ; 8 ; 12$ & 563.9 & 188.6 & 4.3 & 5.1 \\
\hline & \multirow[t]{2}{*}{ Top-slope (Eriophorum) } & 410035 & 394263 & $1-3$ & $100 ; 100 ; 100$ & 563.7 & 166.9 & 4.4 & 4.8 \\
\hline & & 410053 & 394255 & $4-6$ & $100 ; 68 ; 96$ & 562.6 & 150.9 & 6.1 & 4.5 \\
\hline & \multirow[t]{2}{*}{ Upper Mid-slope } & 410108 & 394216 & $1-3$ & $0 ; 0 ; 40$ & 557.5 & 131.3 & 7.4 & 7.1 \\
\hline & & 410069 & 394165 & $4-6$ & $64 ; 48 ; 48$ & 555.4 & 145.7 & 10.8 & 5.6 \\
\hline & \multirow[t]{2}{*}{ Lower Mid-slope } & 410102 & 394100 & $1-3$ & $80 ; 100 ; 100$ & 538.8 & 148.5 & 10.1 & 6.4 \\
\hline & & 410071 & 394065 & $4-6$ & $64 ; 16 ; 28$ & 537.8 & 143.1 & 10.6 & 6.1 \\
\hline & \multirow[t]{2}{*}{ Bottom-slope (Eriophorum) } & 410086 & 393925 & $1-3$ & $100 ; 96 ; 96$ & 522.8 & 136.7 & 4.3 & 5.4 \\
\hline & & 410100 & 393892 & $4-6$ & $96 ; 100 ; 100$ & 521.0 & 146.7 & 2.5 & 5.3 \\
\hline & \multirow[t]{2}{*}{ Bottom-slope (Hummock) } & 410100 & 393900 & $1-3$ & $72 ; 88 ; 52$ & 521.2 & 175.6 & 3.1 & 5.7 \\
\hline & & 410106 & 393888 & $4-6$ & $96 ; 32 ; 80$ & 520.7 & 147.1 & 2.7 & 7.2 \\
\hline
\end{tabular}

water table drawdown as a result of gully edge effects (Allott et al., 2009).

Experiment 2 was conducted on Alport Low, with the four hillslope positions realigned into a transect from the top-slope to the riparian zone (Fig. 1). This experiment was conducted to increase vertical resolution and investigate the connection between the hill- slope and stream network. Twelve hillslope positions were used as part of the slope transect (Table 2), numbered 1-11 (including 1-E Eriophorum spp. plots and 1-H hummock plots) from the top-slope to riparian zone. The top-slope, mid-slope and bottom-slope ostensibly had four individual hillslope positions (Fig. 2), supported by altitudinal and slope angle variation (Table 2), whereby change 
Table 2

Experiment 2 slope position details by study site. 1 -E = Eriophorum and 1-H = hummock plots. Eriophorum dominance numbers refer to plots $1 ; 2 ; 3$.

\begin{tabular}{|c|c|c|c|c|c|c|c|}
\hline Slope position & $X$ & Y & Eriophorum dominance (\%) & Altitude (m) & Aspect $\left({ }^{\circ}\right)$ & Slope angle $\left(^{\circ}\right)$ & Wetness index \\
\hline $1-\mathrm{E}$ & 410035 & 394263 & $100 ; 100 ; 100$ & 563.7 & 166.9 & 4.4 & 4.8 \\
\hline $1-\mathrm{H}$ & 410053 & 394255 & $24 ; 32 ; 20$ & 563.9 & 188.6 & 4.3 & 5.1 \\
\hline 2 & 410065 & 394244 & $20 ; 56 ; 80$ & 561.8 & 136.1 & 4.0 & 4.4 \\
\hline 3 & 410086 & 394231 & $88 ; 68 ; 80$ & 560.4 & 108.0 & 3.8 & 5.9 \\
\hline 4 & 410108 & 394216 & $24 ; 40 ; 48$ & 557.4 & 131.3 & 7.4 & 7.1 \\
\hline 5 & 410139 & 394190 & $12 ; 60 ; 52$ & 552.3 & 144.2 & 11.3 & 5.9 \\
\hline 6 & 410170 & 394165 & $68 ; 20 ; 24$ & 544.5 & 142.3 & 11.2 & 6.2 \\
\hline 7 & 410198 & 394137 & $20 ; 44 ; 100$ & 537.1 & 135.1 & 10.2 & 6.7 \\
\hline 8 & 410203 & 394095 & $100 ; 68 ; 56$ & 532.5 & 135.0 & 4.1 & 6.0 \\
\hline 9 & 410235 & 394059 & $24 ; 60 ; 92$ & 529.5 & 176.8 & 6.4 & 7.9 \\
\hline 10 & 410240 & 394062 & $96 ; 100 ; 96$ & 527.4 & 146.3 & 4.8 & 7.3 \\
\hline 11 & 410264 & 394029 & $76 ; 88 ; 100$ & 525.0 & 145.9 & 4.5 & 6.9 \\
\hline
\end{tabular}

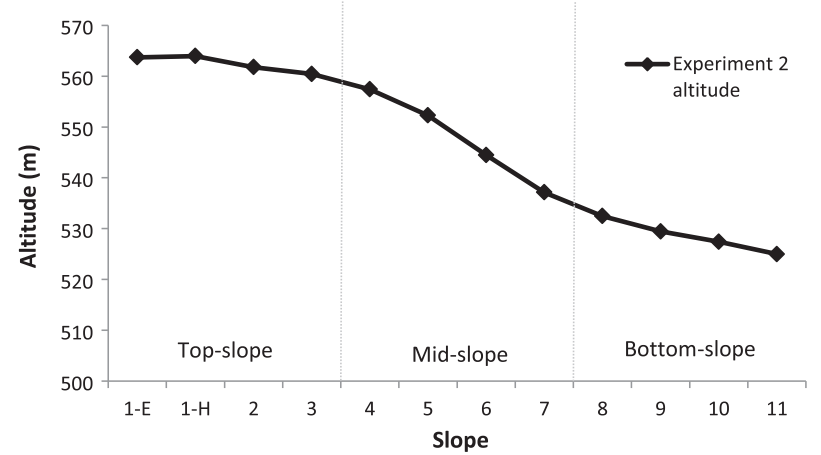

Fig. 2. Experiment 2 slope positions \& altitude, separated into top-slope, mid-slope and bottom-slope.

in elevation was more rapid between slope positions 4-7 which also had slope angles more than $5^{\circ}$. Slope position 9 , on the bottom-slope, was located in a small depression and consequently had a larger slope angle of $6.4^{\circ}$ compared to other bottom-slope positions. The number of study plots per slope position was decreased to three per slope position in Experiment 2. Two stream points were used to collect samples for water quality analysis; one from a stream draining the catchment and another directly draining the bank of peat adjacent to slope position 11. Vegetation surveys were conducted for each plot in November 2012 to determine the percentage cover of Eriophorum spp. classed as dominant vegetation to be used as a covariate in statistical analysis.

Study plots across both study years were comprised of a $1 \mathrm{~m}$ uPVC dipwell and a surface runoff trap. For the dipwells, holes were drilled into the tube every $10 \mathrm{~cm}$ to allow the inflow of water from surrounding peat and the water level in the dipwell to equilibrate with the surrounding peat, thus allowing an accurate measurement of WTD. Dipwells were open-ended and used to collect soil pore water. Runoff traps were closed with bungs at both ends to prevent inflow of soil pore water and precipitation. Holes were drilled in the runoff traps and the traps inserted into the ground until the holes sat flush with the ground surface to allow the inflow of water from across the ground surface.

During Experiment 2, additional $10 \mathrm{~cm}$ depth water traps were installed in March 2012. These traps were designed to assess mixing between water sources and changes in flowpath and the change in water chemistry and DOC concentration that can occur with depth (Adamson et al., 2001; Clark et al., 2008). Two $10 \mathrm{~cm}$ depth traps were installed at each slope position, in between plots 1-2 and plots 2-3. The $10 \mathrm{~cm}$ depth traps were composed of uPVC runoff traps with holes drilled so that when installed the holes were $10 \mathrm{~cm}$ below the peat surface. Just as for the surface runoff traps, bungs were inserted at both ends to prevent mixing with soil pore water from other depths in the peat profile other than $10 \mathrm{~cm}$, or mixing with precipitation. Samples were gathered from these $10 \mathrm{~cm}$ depth samplers for five months between April and August 2012.

All study plots were left for a minimum of one month following installation to allow dissipation of installation effects prior to regular monitoring.

\subsection{Analyses}

Water table depth was measured by conductivity probe with values corrected each month (to allow for shrink/swell of the peat soil) for the height of the dipwell that remained above the surface. Water samples were collected from dipwells, surface runoff water traps, and, when installed, the $10 \mathrm{~cm}$ depth traps; traps, but not dipwells, were emptied each month.

Prior to analysis, water samples were filtered at $\leqslant 0.45 \mu \mathrm{m}$ to remove particulate matter using cellulose-acetate syringe-filters (VWR International). Electrode methods were used to analyse $\mathrm{pH}$ (HI-9025, Hanna Instruments) and electrical conductivity (HI9033). UV-visible absorbance was measured at 400, 465 and $665 \mathrm{~nm}$ using a Jenway $6505 \mathrm{UV} /$ Vis. Measurements made at $400 \mathrm{~nm}\left(\mathrm{Abs}_{400}\right)$ were used to derive a basic colour reading for water samples, whilst measurements at 465 and $665 \mathrm{~nm}$ determined the E4:E6 ratio. More mature humic acids are indicated by lower E4:E6 ratios, with high ratios indicative of fulvic acids (Thurman, 1985). Specific absorbance was established by dividing Abs $_{400}$ by DOC concentration.

DOC was determined using a colourimetric method (Bartlett and Ross, 1988). Oxalic acid standards were used to determine a calibration curve of organic carbon and blanks were run approximately every 12 samples. Detection limits were determined for DOC analysis based upon the last recorded absorbance value where the lower confidence limit of a given DOC concentration was still positive. Absorbance values that caused a negative DOC value on the lower confidence limit were rejected and no DOC concentration data recorded. Anion concentrations of $\mathrm{F}^{-}, \mathrm{Br}^{-}, \mathrm{NO}_{3}^{-}, \mathrm{PO}_{4}^{3-}, \mathrm{Cl}^{-}$and $\mathrm{SO}_{4}^{2-}$ were measured using ion chromatography (Metrohm 761 Compact IC connected to an 813 Compact Auto-sampler). Samples were calibrated against standards with blanks run prior to and following the standards. Further blanks were run between samples from each slope position.

To compare soil pore water and runoff water to precipitation water chemistry, data gathered from the River Etherow (DEFRA, 2013) between 07/06/2010 and 04/01/2012 was used, covering the study period up of experiments 1 and 2 until no more data was available. The River Etherow drains the northern part of Bleaklow Plateau and the monitoring station was located approximately 5.2 and $7.2 \mathrm{~km}$ NNE of Alport Low and Featherbed Moss respectively. 


\subsection{LiDAR terrain parameters}

Environment Agency two-metre ground resolution LiDAR data (with $25 \mathrm{~cm}$ vertical accuracy) of Bleaklow and Kinder Scout, areas of the Peak District, flown in December 2002 and May 2004 (Evans et al., 2005) was used to derive terrain parameters including slope angle, altitude and wetness index for the two study sites. Terrain Analysis System (TAS), an open-source GIS package (Lindsay, 2005), was used to ascertain the terrain indices listed above. The LiDAR data had undergone object removal by the Environment Agency whilst pre-processing was carried out prior to analysis of the LiDAR digital elevation model (DEM), using the Impact Reduction Approach recommended by Lindsay and Creed (2005) to remove artefact depressions in the data. Wetness index (Eq. (1)) was used as a measure for the propensity to saturation across the hillslope, accounting for topographic setting using slope and specific catchment area contributing water supply to a given cell. The wetness index was calculated as:

$W I=\ln \frac{A_{s}}{\tan S}$

where $A_{s}=$ specific catchment area; and $S=$ slope. The FD8 flow algorithm (dispersal in multiple flow-directions) was used. Terrain indices were determined for each nested sub-slope in the Experiment 1 dataset using an average value from the cell containing the location of the sub-slope and the surrounding cells (9 cells including the central sub-slope cell). The terrain indices were included as covariates in statistical analysis.

\subsection{Statistical analysis}

Prior to statistical analysis, values beyond three standard deviations of the mean were removed being assumed to be extreme outlying values. This was a conservative approach that removed only a small percentage of data and improved dataset distribution. For experiment 1, from a dataset of 688 soil pore water samples, 5 $(0.73 \%)$ were removed; for runoff water, of 518 samples, 9 (1.74\%) were removed. No samples were excluded from experiment 2. Values below the limit of detection (which varied between 0.6 and $3.5 \mathrm{mg} \mathrm{Cl}^{-1}$ ) for DOC concentrations were also removed.

Analysis of variance (ANOVA) and covariance (ANCOVA) were used to assess importance of factors, their interactions and covariates within the experimental design. The Anderson-Darling test was used to determine the normality of each dataset; if there was a non-normal distribution, the data was log transformed. The lowest Anderson-Darling statistic was used as the selection criteria for the inclusion of covariates. Levene's test was performed to test the assumption of homogeneity of variances on both untransformed and $\log$ transformed data. Results were also checked using the non-parametric Kruskal-Wallis test to confirm ANOVA results for slope position if the above tests failed. Results for all analyses using the Kruskal-Wallis test were the same as those using ANOVA, confirming the ANOVA results for slope position.

Analysis of variance was undertaken using a General Linear Modelling approach. In Experiment 1, four factors were considered - study site, month of sampling, slope position and sub-slope position. The study site factor had two levels (Featherbed Moss and Alport Low) and is henceforward referred to as the site factor. The seasonal cycle had 12 levels, one representing each calendar month, and henceforward referred to as the month factor. Slope position had four factor levels (top-slope, upper mid-slope, lower mid-slope and bottom-slope). Sub-slope position was taken as a nested factor within the slope position factor and had six levels. The factorial design allowed testing of significant differences for site, slope, sub-slope, month and interaction effects between fac- tors. This approach meant that the impact of slope position could be tested having accounted for the influence of other factors in the model. In particular, note that slope position was replicated because two sites were included in the analysis.

Within Experiment 1, soil pore water and runoff water DOC were analysed separately using the factors described above and then in a separate analysis the soil pore water and runoff water were considered together in a combined analysis with an additional factor - water type - included to assess whether the relationship between slope position and DOC changed with water type.

Experiment 2 incorporated slope (12 factor levels), month and interactions in the ANOVA model.

Each analysis of variance was followed by ANCOVA analysis, whereby covariates (percentage Eriophorum spp., WTD, air temperature, $\mathrm{pH}$, conductivity, $\mathrm{E} 4: \mathrm{E} 6, \mathrm{Cl}^{-}, \mathrm{SO}_{4}^{2-}, \mathrm{NO}_{3}^{-}$and terrain parameters excluding aspect) were included in the model so as to explain any effects that were attributed to the factors used in ANOVA, including slope position.

Tukey's post hoc pairwise comparisons were used to identify the locations of the significant differences identified between factor levels. The proportion of variation in the response variable that is explained by a given factor, interaction or covariate was determined using the generalised omega squared statistic - $\omega^{2}$ (Olejnik and Algina, 2003). Significance was, unless otherwise stated, at the $95 \%$ probability of being different from zero. The size of any effect is discussed in main effects plots using least squares means for factor levels.

Principal components analysis was performed on the Experiment 2 dataset. Water chemistry variables included in the multivariate datasets were: $\mathrm{pH}$; electrical conductivity; absorbance at $400 \mathrm{~nm}\left(\mathrm{Abs}_{400}\right)$; E4:E6 ratio (absorbance $465 / 665 \mathrm{~nm}$ ); specific absorbance ( $\mathrm{Abs}_{400} / \mathrm{DOC}$ concentration); DOC concentration; and $\mathrm{SO}_{4}^{2-}, \mathrm{Cl}^{-}$, and $\mathrm{NO}_{3}^{-}$concentration. The remaining anions of $\mathrm{PO}_{4}^{2-}$, $\mathrm{F}^{-}$and $\mathrm{Br}^{-}$were excluded from analysis due to their low concentrations, which were more often than not below the limit of detection. Prior to analysis, all water chemistry variables were $\mathrm{z}$ transformed to standardise each variable to allow comparison between variables with different measurement units. The selection of principal components (PCs) used in analysis was based upon the convention of using all PCs with an eigenvalue $>1$ and the first PC that has an eigenvalue $<1$ (Chatfield and Collins, 1980). All statistical analysis was performed in Minitab (v14).

\section{Results}

\subsection{Experiment 1}

\subsubsection{Soil pore water}

The DOC concentration in soil pore water varied with hillslope position (Fig. 3). Median DOC concentration was $>90 \mathrm{mg} \mathrm{Cl}^{-1}$ for both the top-slope and upper mid-slope and decreased further down-slope to $72.5 \mathrm{mg} \mathrm{Cl}^{-1}$ on the bottom-slope. When ANOVA was considered then site, slope, sub-slope, month and interactions between site and slope, site and month and slope and month were all significant (Table 3 ). Slope was the second most important (see $\omega^{2}$, Table 3) factor after month, i.e. there was a significant difference between the DOC concentrations in soil water between slope positions that was independent of the site of that slope or of the time of year. The top-slope $\left(105.2 \mathrm{mg} \mathrm{Cl}^{-1}\right.$, least squares mean Fig. 4a) and upper mid-slope (104.9 $\mathrm{mg} \mathrm{Cl}^{-1}$ ) had significantly higher concentrations of DOC than the lower mid-slope (86.1 $\mathrm{mg} \mathrm{Cl}^{-1}$ ), which also had a significantly higher DOC concentration than the bottom-slope $\left(70.1 \mathrm{mg} \mathrm{Cl}^{-1}\right)$.

Least squares mean DOC concentration was significantly higher on Alport Low $\left(104.5 \mathrm{mg} \mathrm{Cl}^{-1}\right)$ than on Featherbed Moss 

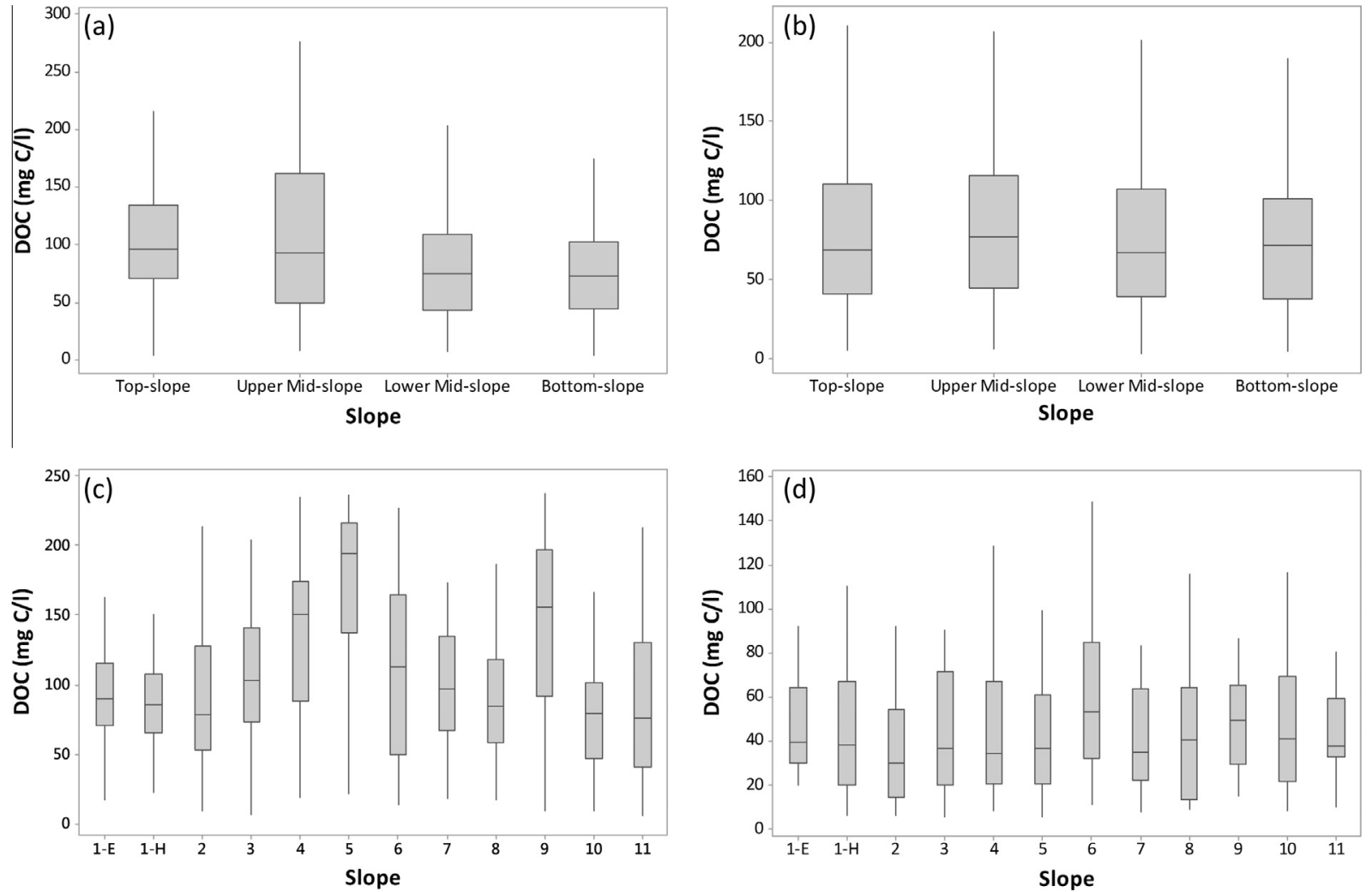

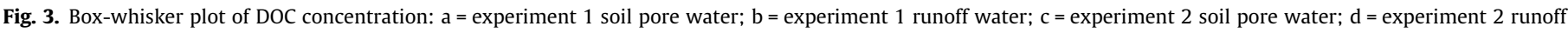
water. The box represents the interquartile range with median line; the whiskers represent the range of values.

Table 3

Experiment 1 soil pore water and runoff water DOC ANOVA/ANCOVA: $\omega^{2}=$ percentage variance; $R^{2}=$ adjusted $R^{2}$. Only significant factors shown.

\begin{tabular}{|c|c|c|c|c|c|}
\hline \multicolumn{3}{|c|}{ Soil pore water DOC ANOVA } & \multicolumn{3}{|c|}{ Soil pore water DOC ANCOVA } \\
\hline Factor & $P$ & $\omega^{2}(\%)$ & Factor/covariate & $P$ & $\omega^{2}(\%)$ \\
\hline Site & $<0.0001$ & 4.31 & WTD & $<0.0001$ & 17.30 \\
\hline Slope & $<0.0001$ & 6.51 & $\mathrm{pH}$ & 0.001 & 1.37 \\
\hline Sub-slope & $<0.0001$ & 0.48 & LnConductivity & $<0.0001$ & 0.21 \\
\hline Month & $<0.0001$ & 23.61 & LnE4:E6 & 0.004 & 0.04 \\
\hline Site $*$ slope & $<0.0001$ & 5.96 & $\mathrm{NO}_{3}^{-}$ & $<0.0001$ & 9.61 \\
\hline Site $*$ month & $<0.0001$ & 4.23 & Slope & $<0.0001$ & 5.06 \\
\hline \multirow[t]{2}{*}{ Slope $*$ month } & $<0.0001$ & 5.51 & Month & $<0.0001$ & 15.52 \\
\hline & & & Slope $*$ month & $<0.0001$ & 3.01 \\
\hline$N 683$ & & $R^{2} 50.63$ & N 598 & & $R^{2} 52.16$ \\
\hline \multicolumn{3}{|c|}{ Runoff DOC ANOVA } & \multicolumn{3}{|c|}{ Runoff DOC ANCOVA } \\
\hline \multirow[t]{4}{*}{ Month } & $<0.0001$ & 24.81 & LnConductivity & 0.001 & 11.67 \\
\hline & & & E4:E6 & $<0.0001$ & 6.73 \\
\hline & & & $\mathrm{LnSO}_{4}^{2-}$ & 0.016 & 1.62 \\
\hline & & & Month & $<0.0001$ & 22.57 \\
\hline$N 509$ & & $R^{2} 24.85$ & N 394 & & $R^{2} 42.65$ \\
\hline
\end{tabular}

(78.6 $\mathrm{mg} \mathrm{Cl}^{-1}$ ) and the differences between the two study sites was notable with the interaction between site and slope. Whereas DOC concentration decreased between the top-slope and lower mid-slope on Featherbed Moss (Fig. 4a), it increased between the top-slope and upper mid-slope on Alport Low and was still higher on the lower mid-slope than the top-slope. Nonetheless, both study sites had a large decrease in DOC concentration between the top-slope and bottom-slope.

The soil water DOC concentration was lower in the months between December and March and for the month of May than between June and November. There appeared to be two distinct

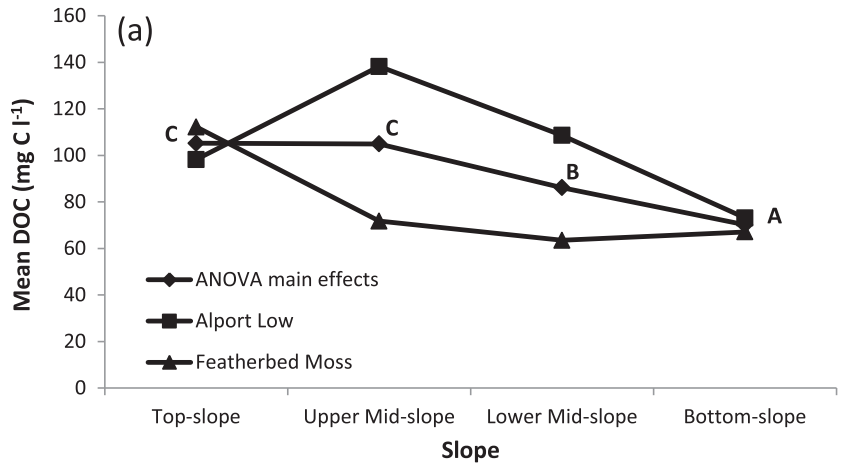

(b)

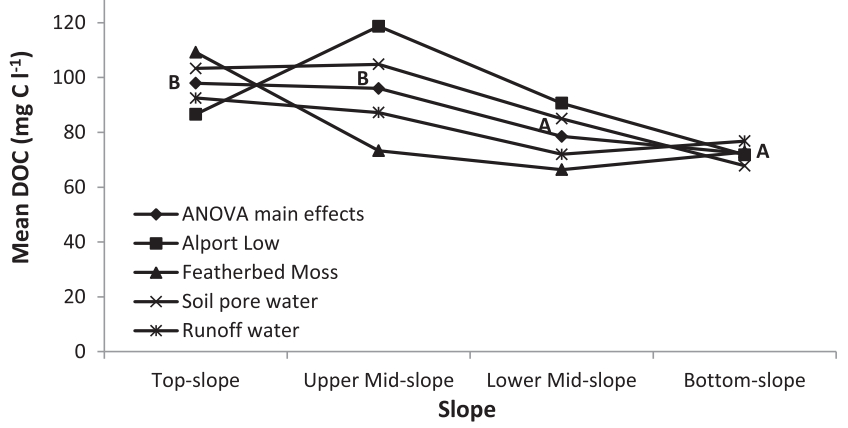

Fig. 4. (a) Experiment 1 soil pore water and (b) experiment 1 water type: DOC ANOVA main effects (given as least squares means) \& interaction plot: significant differences for the main effects denoted where letters are not shared between slope positions. 
Table 4

Experiment 1 water type DOC ANOVA/ANCOVA: $\omega^{2}=$ percentage variance; $R^{2}=$ adjusted $R^{2}$. Only significant factors shown.

\begin{tabular}{|c|c|c|c|c|c|}
\hline \multicolumn{3}{|l|}{ DOC ANOVA } & \multicolumn{3}{|l|}{ DOC ANCOVA } \\
\hline Factor & $P$ & $\omega^{2}(\%)$ & Factor & $P$ & $\omega^{2}(\%)$ \\
\hline Site & $<0.0001$ & 1.17 & LnConductivity & 0.005 & 0.74 \\
\hline Slope & $<0.0001$ & 3.04 & E4:E6 & 0.011 & 3.32 \\
\hline Sub-slope & 0.005 & 0.11 & $\mathrm{LnSO}_{4}^{2-}$ & 0.002 & 0.19 \\
\hline Water type & 0.002 & 1.07 & $\mathrm{NO}_{3}^{-}$ & $<0.0001$ & 5.05 \\
\hline Month & $<0.0001$ & 22.21 & Site & 0.006 & 0.91 \\
\hline Site $*$ slope & $<0.0001$ & 3.76 & Slope & $<0.0001$ & 2.70 \\
\hline Site $*$ water type & $<0.0001$ & 0.86 & Sub-slope & 0.025 & 0.62 \\
\hline Site $*$ month & $<0.0001$ & 1.46 & Water type & $<0.0001$ & 3.99 \\
\hline Slope $*$ water type & 0.001 & 0.86 & Month & $<0.0001$ & 18.65 \\
\hline Slope $*$ month & $<0.0001$ & 3.02 & Site $*$ slope & $<0.0001$ & 4.24 \\
\hline Water type $*$ month & $<0.0001$ & 2.30 & Site $*$ water type & $<0.0001$ & 1.48 \\
\hline \multirow[t]{4}{*}{ Slope $*$ water type $*$ month } & 0.015 & 1.02 & Site $*$ month & $<0.0001$ & 2.84 \\
\hline & & & Slope $*$ water type & $<0.0001$ & 1.78 \\
\hline & & & Slope $*$ month & $<0.0001$ & 2.68 \\
\hline & & & Water type $*$ month & $<0.0001$ & 1.73 \\
\hline N 1192 & & $R^{2} 40.91$ & $N 1061$ & & $R^{2} 50.94$ \\
\hline
\end{tabular}

phases characterising seasonal change in DOC concentration. Between June and October, DOC concentrations increased to a maximum of $135.2 \mathrm{mg} \mathrm{Cl}^{-1}$ and thereon decreased to $53.8 \mathrm{mg} \mathrm{l}^{-1}$ in December. This pattern was repeated between January 2011 and April 2011, when DOC concentration increased, before declining in May. The December DOC concentration of the bottom-slope decreased to a much smaller extent than other slope positions - for example the upper mid-slope decreased by $98.8 \mathrm{mg} \mathrm{Cl}^{-1}$ compared to $6.4 \mathrm{mg} \mathrm{Cl}^{-1}$ on the bottom-slope.

When covariates were included in the analysis (ANCOVA), the amount of variance explained by each factor was reduced and study site and sub-slope were no longer significant. The most important covariate was WTD. The negative correlation between depth to the water table and soil water DOC concentration accounted for the influence of study site and sub-slope. Post hoc comparisons in the ANCOVA model show that the top-slope had a significantly greater DOC concentration than all other hillslope positions (Table 3 ). The least squares mean main effects DOC concentrations were $103.9,82.5,77.5$ and $85.3 \mathrm{mg} \mathrm{Cl}^{-1}$ for the topslope, upper mid-slope, lower mid-slope and bottom-slope respectively. The change in least squares mean values suggests that the high DOC concentrations on the Alport Low upper mid-slope were caused by deeper water tables at this site. Accounting for this, the upper mid-slope was no longer significantly different from the lower mid-slope and bottom-slope. $\mathrm{pH}$ and conductivity were positively correlated, while $\mathrm{NO}_{3}^{-}$was negatively correlated to soil pore water DOC concentration. Despite the influence of the hydrochemistry covariates and WTD upon DOC concentration, they did not account for the higher DOC concentrations observed on the topslope. As such, there was a significant effect of slope position independent of covariates and all other factors and their possible 2-way interactions.

\subsubsection{Runoff water}

Median values of runoff water (Fig. 3) suggested there was little difference in DOC concentration with slope position, though the upper mid-slope $\left(77.7 \mathrm{mg} \mathrm{Cl}^{-1}\right.$ ) was higher than the other slope positions, which ranged from 67.1 to $71.8 \mathrm{mg} \mathrm{Cl}^{-1}$. The DOC concentrations were generally lower in runoff water than soil pore water. Month was the only significant factor in the ANOVA model (Table 3); no slope effect was found for runoff water DOC. July (114.8 $\mathrm{mg} \mathrm{Cl}^{-1}$ ) had the highest DOC concentration, with the lowest occurring in December (34.6 $\mathrm{mg} \mathrm{Cl}^{-1}$ ). In general, runoff water DOC increased from winter lows to maxima in the summer. DOC concentrations in June and July were significantly higher than both winter and spring months, while DOC in September and October was higher than winter months. The ANCOVA (Table 3) indicated that conductivity, E4:E6 and $\mathrm{SO}_{4}^{2-}$ were significant covariates. Conductivity was positively correlated with DOC as was $\mathrm{SO}_{4}^{2-}$ concentration. The positive correlation between DOC and E4:E6 was the reverse of that for soil pore water. The amount of variation explained by month reduced.

\subsubsection{Water type}

Soil pore water and runoff water were analysed together, to assess whether the relationship between DOC concentration and water type changed between slope positions. The ANOVA model (Table 4) indicated that all factors were significant in the model, with significant interactions between all factors (barring nested sub-slope). The main effects indicated a least squares mean of $82.1 \mathrm{mg} \mathrm{Cl}^{-1}$ for runoff water and $90.2 \mathrm{mg} \mathrm{Cl}^{-1}$ for soil pore water, while the relationship between slope and DOC concentration was similar to that in the soil pore water ANOVA model. The DOC concentration was significantly higher on the top-slope (97.9 $\mathrm{mg} \mathrm{Cl}^{-1}$, Fig. 4b) and upper mid-slope $\left(96.0 \mathrm{mg} \mathrm{Cl}^{-1}\right)$ than the lower midslope (78.5 $\left.\mathrm{mg} \mathrm{Cl}^{-1}\right)$ and bottom-slope $\left(72.3 \mathrm{mg} \mathrm{Cl}^{-1}\right)$. Unlike the soil pore water DOC ANOVA model, there was no significant difference between the lower mid-slope and bottom-slope. The interaction between site and slope showed the same trends as in the soil pore water model. However, the interaction between slope and water type showed that although soil pore water had a greater DOC concentration than runoff water for the top-slope to lower mid-slope, runoff water had a greater DOC concentration than soil pore water on the bottom-slope.

The addition of covariates in ANCOVA increased the adjusted $R^{2}$ to $50.94 \%$ from $40.91 \%$. The most important covariate was $\mathrm{NO}_{3}^{-}$ which explained $5.05 \%$ of dataset variation and had a negative correlation with DOC concentration, as in the soil pore water ANCOVA. The E4:E6 explained $3.32 \%$ of variation in the dataset and had a positive correlation to DOC, reflecting its importance in discriminating runoff water. Conductivity and $\mathrm{SO}_{4}^{2-}$ had significant positive correlations to DOC concentration, but explained $<1 \%$ variation combined. The amount of variation explained by water type increased, as also for the interaction between slope and water type. Main effects indicated a greater difference in runoff water and soil pore water DOC concentration (62.2 and $97.4 \mathrm{mg} \mathrm{Cl}^{-1}$ ) compared to the ANOVA model. Significant differences for slope position remained the same as the ANOVA model, while DOC concentration in soil pore water was greater across all slope positions than runoff water having accounted for the effect of covariates. 
Table 5

Experiment 2 soil pore water and runoff water DOC ANOVA/ANCOVA: $\omega^{2}=$ percentage variance; $R^{2}=$ adjusted $R^{2}$. Only significant factors shown.

\begin{tabular}{|c|c|c|c|c|c|}
\hline \multicolumn{3}{|c|}{ Soil pore water DOC ANOVA } & \multicolumn{3}{|c|}{ Soil pore water DOC ANCOVA } \\
\hline Factor & $P$ & $\omega^{2}(\%)$ & Factor & $P$ & $\omega^{2}(\%)$ \\
\hline Slope & $<0.0001$ & 19.61 & WTD & $<0.0001$ & 27.27 \\
\hline Month & $<0.0001$ & 24.56 & LnConductivity & $<0.0001$ & 8.78 \\
\hline \multirow[t]{5}{*}{ Slope-month } & 0.001 & 9.55 & $\mathrm{NO}_{3}^{-}$ & $<0.0001$ & 7.21 \\
\hline & & & $\mathrm{LnSO}_{4}^{2-}$ & 0.014 & 0.52 \\
\hline & & & Slope & $<0.0001$ & 4.78 \\
\hline & & & Month & $<0.0001$ & 7.44 \\
\hline & & & Slope-month & $<0.0001$ & 10.26 \\
\hline$N 411$ & & $R^{2} 53.78$ & $N 371$ & & $R^{2} 66.32$ \\
\hline \multicolumn{3}{|c|}{ LnRunoff water DOC ANOVA } & \multicolumn{3}{|c|}{ LnRunoff DOC ANCOVA } \\
\hline \multirow[t]{4}{*}{ Month } & $<0.0001$ & 13.13 & $\mathrm{pH}$ & $<0.0001$ & 0.22 \\
\hline & & & LnE4:E6 & $<0.0001$ & 14.75 \\
\hline & & & $\mathrm{LnSO}_{4}^{2-}$ & $<0.0001$ & 19.02 \\
\hline & & & Month & 0.019 & 3.49 \\
\hline$N 292$ & & $R^{2} 13.17$ & N 215 & & $R^{2} 37.59$ \\
\hline
\end{tabular}

\subsection{Experiment 2}

\subsubsection{Soil pore water}

Median soil pore water DOC concentration on the slope transect (Fig. 3) was largest on slope position $5\left(193.9 \mathrm{mg} \mathrm{Cl}^{-1}\right)$ and was very high on slope position $9\left(155.7 \mathrm{mg} \mathrm{Cl}^{-1}\right)$ and slope position 4 (150.7 $\mathrm{mg} \mathrm{Cl}^{-1}$ ). The DOC concentration was lower on the topmost slope positions $\left(85.8 \mathrm{mg} \mathrm{Cl}^{-1}, 1-\mathrm{H}\right)$ and decreased downslope from slope position 5 , to a low at slope position 11 (76.2 $\mathrm{mg} \mathrm{Cl}^{-1}$ ).

Slope, month and a slope-month interaction were significant in the ANOVA model (Table 5) of soil pore water DOC. Slope positions 4, 5 and 9 all had significantly higher DOC concentrations than most other slope positions. Unlike in Experiment 1, there was no significant difference in DOC concentration between top-slope plots and those on the bottom-slope beyond slope position 9. However, the main effects (Fig. SI1) were broadly similar to the Alport Low site-slope interaction (Fig. 4a) and the decrease in DOC concentration further down the mid-slope was consistent with results from Experiment 1. Slope position $9\left(148.3 \mathrm{mg} \mathrm{Cl}^{-1}\right)$ had significantly higher DOC than adjacent slope positions, perhaps reflecting the importance of microtopographic variation. The DOC concentrations in the autumn were significantly higher than most months excluding May, showing a significant decrease in DOC in January. The decrease in DOC between November and January was consistent between the two datasets of Experiments 1 and 2 .

Water table depth, conductivity, $\mathrm{NO}_{3}^{-}$and $\mathrm{SO}_{4}^{2-}$ were significant covariates (Table 5), reducing the importance of slope position. The

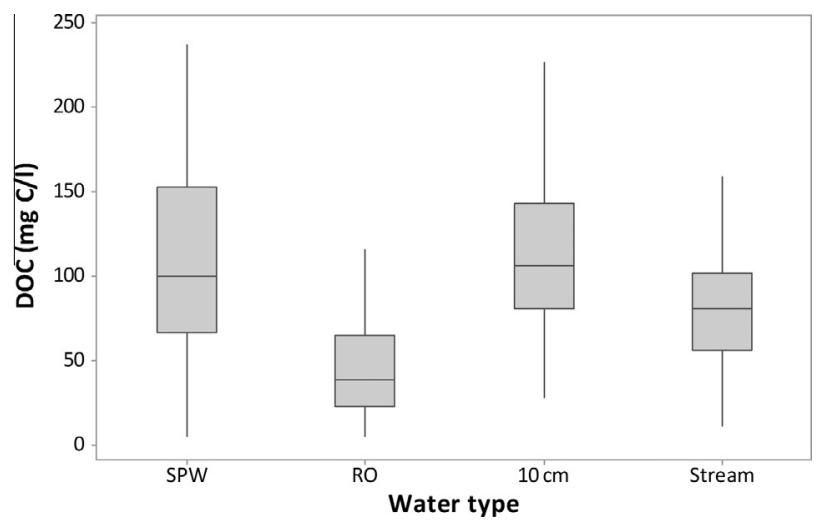

Fig. 5. Box-whisker plot of experiment 2 DOC concentration by water type: $\mathrm{SPW}=$ soil pore water; $\mathrm{RO}=$ runoff water; $10 \mathrm{~cm}=10 \mathrm{~cm}$ water (April-August 2012). The box represents the interquartile range with median line; the whiskers represent the range of values. significant differences suggested that $1-\mathrm{H}$, a top-slope position, was lower in DOC than most others. The high DOC concentrations on the mid-slope positions were caused by deeper water tables and accounting for WTD and the other hydrological covariates reduced least squares means of mid-slope DOC concentrations. Indeed, slope position 4 was significantly lower than slope position 5 . The high DOC concentrations observed at slope position 9, a bottom-slope position, were no longer significantly different to adjacent plots having accounted for WTD. The importance of WTD in controlling DOC concentration and removing most of the slope effects observed in the ANOVA model corroborated results from Experiment 1. Moreover, the increased importance of conductivity compared to Experiment 1 may suggest the slope transect better captured variation in DOC associated with hydrological changes.

\subsubsection{Runoff water}

Runoff water DOC concentration (Fig. 3) was lower than that of soil pore water. The highest median DOC concentration was at slope position $6\left(53.6 \mathrm{mg} \mathrm{Cl}^{-1}\right)$ and lowest at slope position 2 (30.2 $\mathrm{mg} \mathrm{Cl}^{-1}$ ). Only the month factor was significant in the ANOVA model (Table 5), in agreement with Experiment 1. The DOC concentration was highest in May and lowest in February and varied between months with no clear distinction between winter and summer. The covariates $\mathrm{pH}, \mathrm{E} 4: \mathrm{E} 6, \mathrm{SO}_{4}^{2-}$ and month were significant in the ANCOVA model. The $\mathrm{pH}$ had a negative correlation to $\mathrm{DOC}$, with a positive correlation for $\mathrm{E} 4$ : $\mathrm{E} 6$ and $\mathrm{SO}_{4}^{2-}$ which agreed with results from Experiment 1.

\subsubsection{Water type}

Median DOC concentration (Fig. 5) in soil pore water was $100.5 \mathrm{mg} \mathrm{Cl}^{-1}$, smaller than the median of $106.8 \mathrm{mg} \mathrm{Cl}^{-1}$ of $10 \mathrm{~cm}$ water, though that was only collected in spring and summer months. Stream water had a lower DOC concentration than both soil pore water and $10 \mathrm{~cm}$, with a median of $81.3 \mathrm{mg} \mathrm{Cl}^{-1}$ but this was nonetheless higher than that of runoff water, which had the lowest median concentration at $38.7 \mathrm{mg} \mathrm{Cl}^{-1}$.

\subsection{Principal components analysis}

From a total of 650 data points, the first five principal components were used in PCA, explaining a total of $87.6 \%$ variation in the dataset (Table 6). Principal component 1 had high positive loadings for $\mathrm{pH}$, conductivity and $\mathrm{SO}_{4}^{2-}$, while negative loadings were dominated by $\mathrm{Abs}_{400}$, specific absorbance and E4:E6: dissolved organic carbon concentration also had a strong negative loading. Dissolved organic carbon had the strongest loading on PC2 and $\mathrm{Abs}_{400}$ was correlated with it as well. However, conductivity, $\mathrm{Cl}^{-}$and $\mathrm{SO}_{4}^{2-}$ also had positive loadings on $\mathrm{PC} 2$. The $\mathrm{PC} 3$ was dominated by negative loadings of $\mathrm{NO}_{3}^{-}$and E4:E6 ratio and PC4 had positive loadings of $\mathrm{Cl}^{-}$and specific absorbance and a negative loading for DOC. Chloride and specific absorbance dominated PC5,

Table 6

The first five principal components of Experiment 2 dataset

\begin{tabular}{|c|c|c|c|c|c|}
\hline Variable & PC1 & PC2 & PC3 & PC4 & PC5 \\
\hline $\mathrm{pH}$ & 0.476 & -0.013 & 0.128 & -0.080 & -0.183 \\
\hline Cond & 0.381 & 0.469 & -0.176 & 0.079 & -0.242 \\
\hline $\mathrm{Abs}_{400}$ & -0.415 & 0.397 & 0.037 & -0.052 & -0.246 \\
\hline E4:E6 & -0.313 & 0.078 & -0.435 & -0.097 & -0.094 \\
\hline DOC & -0.264 & 0.487 & 0.023 & -0.557 & 0.250 \\
\hline Specific absorbance & -0.346 & 0.056 & -0.034 & 0.512 & -0.558 \\
\hline $\mathrm{SO}_{4}^{2-}$ & 0.404 & 0.364 & -0.202 & -0.125 & -0.301 \\
\hline $\mathrm{Cl}^{-}$ & 0.059 & 0.452 & 0.000 & 0.622 & 0.591 \\
\hline $\mathrm{NO}_{3}^{-}$ & 0.045 & -0.198 & -0.848 & 0.014 & 0.160 \\
\hline$\%$ Variance & $39.1 \%$ & $54.9 \%$ & $67.1 \%$ & $78.2 \%$ & $87.6 \%$ \\
\hline
\end{tabular}




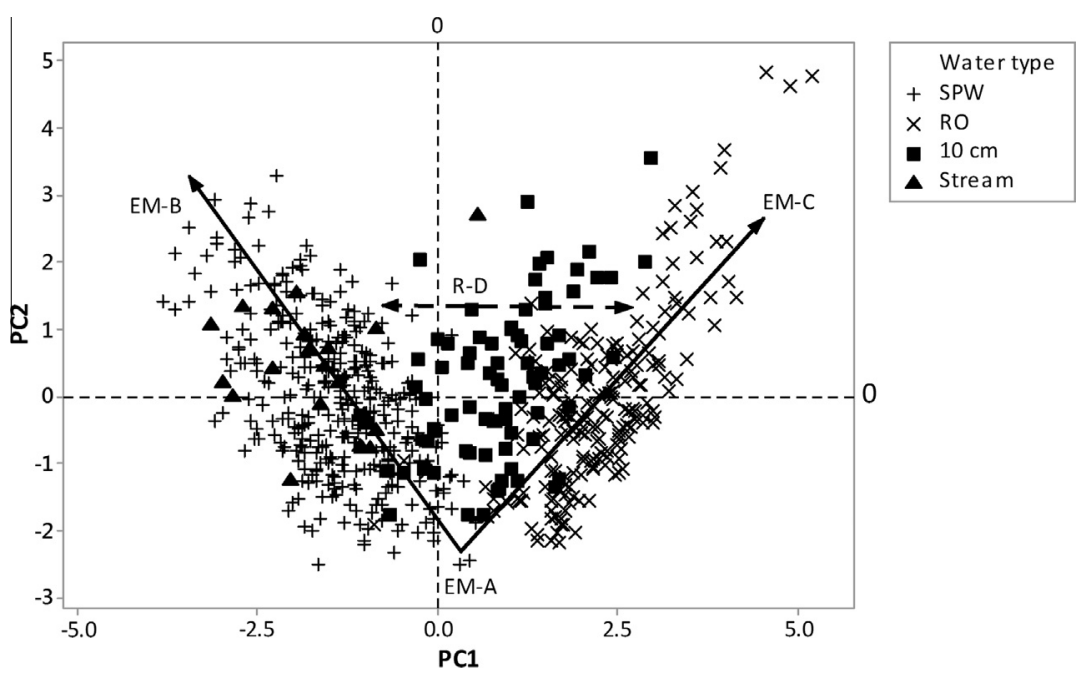

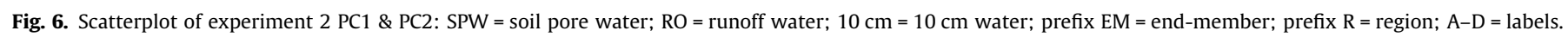

with a positive loading for $\mathrm{Cl}^{-}$and negative loading for specific absorbance.

Comparing scores for data on PC1 and PC2 (Fig. 6) indicated that PC1 distinguished between water types and showed minimal overlap between soil pore water and runoff water. Instead, $10 \mathrm{~cm}$ water plotted predominantly between soil pore water and runoff water, reflecting the transition between the deeper old water and new precipitation inputs and suggesting the mixing of soil pore water and runoff water predominated in the upper layers. Three endmembers were evident from Fig. 6. End-Member-A (EM-A) was a compositional end-member from which soil pore water and runoff water evolved. The EM-A was represented by two soil pore water samples, from slope position 2 in June 2012 and slope position 3 in February 2012. The characteristic features of EM-A were low: conductivity; low $\mathrm{SO}_{4}^{2-}, \mathrm{Cl}$ and $\mathrm{DOC}$ concentrations; low E4:E6 ratios, $\mathrm{Abs}_{400}$ and specific absorbance.

Soil pore water composition evolved from EM-A towards endmember B (EM-B - Fig. 6), which was characterised by very high DOC concentrations and specific absorbance but was particularly distinguished by very high $\mathrm{Abs}_{400}$. The EM-B was typically a deep soil pore water end-member. Slope positions 9, 4 and 5, which had deep water tables, dominated EM-B. Top-slope positions $1-\mathrm{H}$ and 3 also had some samples located at EM-B. Though stream water DOC concentrations were between those of soil pore water and runoff water PCA suggested its water chemistry plotted along the soil pore water trend, due to its typically low conductivity, $\mathrm{pH}$ and $\mathrm{SO}_{4}^{2-}$ and high $\mathrm{Abs}_{400}$ and specific absorbance.

Runoff water evolved from EM-A towards end-member-C (EM-C - Fig. 6), where samples had high conductivity, $\mathrm{SO}_{4}^{2-}$ and $\mathrm{pH}$ but very low specific absorbance and $\mathrm{Abs}_{400}$. The composition of $10 \mathrm{~cm}$ water helped to demonstrate the change in water chemistry between soil pore water and runoff water, as shown along the area R-D (Fig. 6). Where $10 \mathrm{~cm}$ water plotted with runoff water, $\mathrm{pH}$ was high, as was either $\mathrm{SO}_{4}^{2-}$ or $\mathrm{Cl}^{-}$. Specific absorbance and $\mathrm{Abs}_{400}$ were low where $10 \mathrm{~cm}$ water and runoff water overlapped, but $10 \mathrm{~cm}$ water DOC concentration was high; as $10 \mathrm{~cm}$ water samples evolved along PC1 towards a soil pore water composition, specific absorbance and $\mathrm{Abs}_{400}$ increased (relative for $10 \mathrm{~cm}$ water). $\mathrm{pH}$ also decreased but was not as low as soil pore water or stream water.

\section{Discussion}

The DOC concentration was shown to significantly vary with slope position, independent of site or available covariates, and decreased down-slope in soil pore water. A slope effect on DOC concentration and DOC flux has been observed for other, nonpeat catchments, with low concentrations on the hillslope and higher concentrations in riparian zones more important to DOC export in the stream (Laudon et al., 2011; Mei et al., 2012; Morel et al., 2009). However, these studies were from catchments where soils on the hillslope were non-peat soils that had low organic content and lower DOC concentrations as a consequence. Wetland soils in the riparian zone had higher organic content and therefore contributed to higher DOC concentrations in the stream. As such the impact of hillslope on DOC across the peatland catchments studied here was quite different.

The importance of hillslope to DOC production and transport in peatland systems can be explained by several mechanisms. Water table depth exerted a strong control upon DOC concentration at both sites - likely due to both enhanced oxidative production and increased residence time leading to a build-up of humic, Crich compounds. There was also an accumulation of water at the base of the hillslope, with higher water tables maintained via runoff and throughflow from upslope locations. The high water tables and throughflow leads to flushing of DOC from the bottom-slope towards the stream. Furthermore, bottom-slope DOC concentrations are further reduced by the mixing of soil pore water and precipitation leading to dilution effects. The effect of water movement and hydro-chemical mixing upon DOC concentration and composition is reflected in runoff water, where no significant slope effects were found. The mechanisms that explain the role of hillslope position in DOC cycling shall be discussed in detail below, yet the influence of hillslope position could not be fully explained by these mechanisms and processes (there was a slope effect independent of covariates).

Slope specific DOC effects have been observed across many environments. Boyer et al. (1997) reported higher DOC concentrations on hillslopes than in the riparian zone due to increased throughflow of subsurface water flushing DOC into the stream. The results of Boyer et al. (1997) would support observations found in this study, but the study was not in peatlands and the scale was limited, classing hillslope as an area $10 \mathrm{~m}$ from the stream where a break in slope was observed, with the riparian zone on steeper ground. Here, the distance between the top-slope and bottomslope on Featherbed Moss and Alport Low in experiment 1 was $\sim 583 \mathrm{~m}$ and $\sim 393 \mathrm{~m}$ respectively. The distance between slope position 1-E and 11 in experiment 2 was $\sim 334 \mathrm{~m}$. Other studies have also commented upon the importance of the riparian zone or wetland areas across different soil types in contributing to 
stream water DOC (Hinton et al., 1998; Mei et al., 2012; Strohmeier et al., 2013), with little effect from the hillslope. Hinton et al. (1998) and Cory et al. (2007) found mineral soil hillslopes had lower DOC concentrations than lower wetland areas that had organic rich soils, though Creed et al. (2013) suggested mid-slope areas and lower wetland zones had lower DOC concentrations than at the base of the hillslope in accumulation areas.

Thus the response of the hillslope and the hydrological connection between the hillslope, riparian zone and stream can depend upon soil type. For this study, it was evident that DOC concentrations in peatlands decreased towards the bottom-slope and emphasises both the importance of monitoring DOC concentrations at the hillslope scale and the dominant effect that hydrology can have in controlling DOC concentration. Indeed, Experiment 1 suggested that elevated DOC concentrations on Alport Low compared to Feathered Moss were the consequence of water table drawdown and this was confirmed using the slope transect. The significance of WTD to DOC concentration would imply the importance of oxidative production of DOC (Scott et al., 1998; Wallage et al., 2006). Increased colour content in water (Mitchell and McDonald, 1995) and seasonal variation in specific absorbance (Worrall et al., 2006) has been related to water table variation. Thus, elevated concentrations in soil pore water (as implied by PCA) may reflect increased residence time and old water rich in colour from humic substances, particularly on mid-slopes where water table drawdown lead to a build-up of DOC at depth. Furthermore, where $10 \mathrm{~cm}$ water plotted adjacent to soil pore water, it had a higher specific absorbance than when it plotted with surface runoff, indicating a greater influence of water colour and humic compounds in soil pore water. Wallage and Holden (2010) also noted a change in the relationship between DOC and colour with depth. As such, closer to the surface, DOC was composed of labile material with low absorbance. Consequently, the lower DOC concentrations found in surface runoff were likely due to dilution of near surface water from precipitation.

The oxidation of sulphur to $\mathrm{SO}_{4}^{2-}$ during water table drawdown has been shown to enhance soil water acidity and suppress DOC solubility (Clark et al., 2009; Evans et al., 2012). Such an effect has been observed at Moor House in the North Pennines (Clark et al., 2005) and with the presence of erosion gullies (Daniels et al., 2008), yet the effect of sulphur oxidation suppressing DOC solubility is equivocal at these sites, only explaining a small amount of variation in DOC in Experiment 2. It is likely that the source of $\mathrm{SO}_{4}^{2-}$ was from near surface peat layers given the low concentrations found in precipitation (mean $=0.52 \pm 0.04 \mathrm{mg} \mathrm{l}^{-1}$, DEFRA, 2013) as well as high levels of historic $\mathrm{SO}_{4}^{2-}$ found in peat deposits in the South Pennines, including on Featherbed Moss (Coulson et al., 2005). Given the particularly high concentrations of $\mathrm{SO}_{4}^{2-}$ in $10 \mathrm{~cm}$ and runoff water, it is probable that $\mathrm{SO}_{4}^{2-}$ was sourced from the upper layers of peat where sulphur was oxidised and mobilised into $10 \mathrm{~cm}$ water and surface runoff. Indeed, Adamson et al. (2001) observed higher concentrations of $\mathrm{SO}_{4}^{2-}$ at $10 \mathrm{~cm}$ depth than $50 \mathrm{~cm}$ in soil pore water, which derived $\mathrm{SO}_{4}^{2-}$ through down profile diffusion. Thus the significance of $\mathrm{SO}_{4}^{2-}$ in ANCOVA models most likely reflects dilution processes and not any effect associated with DOC solubility suppression. Slope position was not significant in explaining variation in DOC for surface runoff water, due to the uniform dilution of DOC across the hillslope when near surface water mixed with precipitation.

A flushing mechanism was identified between autumn and winter months, as noted in the stream water chemistry of Moor House in the North Pennines (Worrall et al., 2005, 2006) and soil pore water across varying gully morphologies on Bleaklow Plateau in the South Pennines (Clay et al., 2012). Increased precipitation likely diluted DOC concentrations and explained the large decrease in DOC between November and December in Experiment 1, which was nearly $100 \mathrm{mg} \mathrm{Cl}^{-1}$ on the upper mid-slope. Dissolved organic carbon concentrations on the top-slope and mid-slopes were lower than the bottom-slope during December - indicating seasonal variation in the relationship between hillslope position and DOC concentration. The above results could suggest that the flushing mechanism did not dilute DOC concentrations on the bottomslope to the extent of other slope positions, perhaps because some DOC on the bottom-slope had already been removed due to water movement from upslope and saturated water tables.

In peatlands, DOC concentration could be expected to decrease with increased discharge due to dilution by precipitation and mixing with surface runoff water (Clark et al., 2008; Stutter et al., 2012). The lower DOC concentrations observed in the stream may be consistent with this, yet stream water retained the high $\mathrm{Abs}_{400}$ and low $\mathrm{pH}$ of soil pore water and plotted along the soil pore water trend in PCA. Indeed, given that mean $\mathrm{Abs}_{400}$ was higher than soil pore water but DOC lower, stream water had a higher specific absorbance. This was because sampling took place under low flow conditions (the author's observation). The $\mathrm{Abs}_{400}$ may have been diluted with increased inputs from surface runoff water and near surface throughflow, and therefore a higher resolution sampling strategy when assessing stream water chemistry would have provided important insights into the change in water chemistry at high flow during rainfall events, as shown by Gazovic et al. (2013).

The link between the hillslope and stream could have important implications for the export of DOC to the stream. Although slope positions higher upslope had higher DOC concentrations in soil pore water, their contribution to stream water DOC is likely lower than on the bottom-slope, where high water tables and water movement from upslope diluted and flushed DOC from the soil towards the stream. Parry et al. (2015) studied DOC concentrations from spot samples in peatland catchments and related it to topography and vegetation. It was found that slope angle was the most important factor that influenced stream water DOC concentration, with a negative correlation indicating that DOC concentration in streams was greatest in areas with low slope angles. It was suggested that this was because gently sloping areas could accumulate more DOC due to lower runoff rates and were more favourable to peat formation than steeper slopes, providing more peat that can be decomposed to produce DOC that is transported to streams. This paper has found that steeper slopes have higher DOC concentrations because of very low water tables allowing both a greater aerobic zone for oxidative decomposition of peat producing DOC and the accumulation of humic compounds with a long residence time. Nonetheless, the interpretation that the bottom-slope contributes more to DOC flux to streams is consistent with the findings of Parry et al. (2015) given that the flushing of DOC from the bottom-slope to the stream will increase the amount of DOC in the stream. Furthermore, it is possible that the alongside the removal of DOC to the stream, if phenolic compounds that inhibit peat decomposition (Freeman et al., 2001b) are also exported to the stream, it could enhance anaerobic production of peat and increase DOC production, providing further DOC that is exported to the stream. A further consideration is the effect that hillslope position has on $C$ budgets. Dissolved organic carbon flux is a major component of peatland $C$ budgets and can affect the size of a $C$ sink or convert catchments into sources of $C$ for some years (Koehler et al., 2011; Nilsson et al., 2008; Roulet et al., 2007). Hillslope position could therefore be used to improve $C$ budget models by increasing the spatial representation of DOC flux and could be incorporated into models such as Worrall et al. (2009b).

\section{Conclusions}

Hillslope position was a significant factor controlling soil pore water DOC concentrations across two hillslopes and two study 
years, but not for surface runoff water DOC concentrations. There was a large decrease in DOC down-slope. Water table drawdown increased DOC concentration, due to enhanced DOC production and increased residence time leading to the build-up of humicrich DOC compounds, particularly on the steeper, eroded slopes. Decreasing soil pore water DOC down-slope and the much lower concentrations of DOC in runoff suggested dilution of DOC as water moves down-slope, caused by rising water tables towards the surface and flushing by lateral throughflow of water.

Water sampled at $10 \mathrm{~cm}$ depth was shown to be intermediate in composition between soil pore water and surface runoff water, characterised by higher $\mathrm{SO}_{4}^{2-}$ concentrations, conductivity and $\mathrm{pH}$ than soil pore water but also much higher DOC concentrations than found in surface runoff water. As such, surface runoff water originated from near surface layers but DOC was diluted relative to $10 \mathrm{~cm}$ water. As water transferred to the stream, DOC concentrations were reduced relative to soil pore water, yet stream water retained the chemical signature of soil pore water under low flow conditions and had higher colour content than soil pore water.

Dissolved organic carbon is an important component of peatland carbon budgets and can affect whether catchments are sources or sinks of carbon. Hillslope position has been shown to affect DOC concentrations and should be incorporated into carbon budget models to improve spatial predictions.

\section{Acknowledgements}

The authors would like to thank Moors for the Future for providing access to the sites and supplying the LiDAR data. Simon Dixon and Suzane Qassim provided valuable field assistance.

\section{Appendix A. Supplementary material}

Supplementary data associated with this article can be found, in the online version, at http://dx.doi.org/10.1016/j.jhydrol.2015.10. 002 .

\section{References}

Adamson, J.K., Scott, W.A., Rowland, A.P., Beard, G.R., 2001. Ionic concentrations in a blanket peat bog in northern England and correlations with deposition and climate variables. Eur. J. Soil Sci. 52 (1), 69-79.

Allott, T.E.H., Evans, M.G., Lindsay, J.B., Agnew, C.T., Freer, J.E., Jones, A., Parnell, M., 2009. Water Table in Peak District Blanket Peatlands: Moors for the Future Report No 17.

Bartlett, R.J., Ross, D.S., 1988. Colorimetric determination of oxidizable carbon in acid soil solutions. Soil Sci. Soc. Am. J. 52 (4), 1191-1192.

Billett, M.F., Dinsmore, K.J., Smart, R.P., Garnett, M.H., Holden, J., Chapman, P., Baird, A.J., Grayson, R., Stott, A.W., 2012. Variable source and age of different forms of carbon released from natural peatland pipes. J. Geophys. Res. Biogeosci. 117, 16.

Bower, M.M., 1961. The distribution of erosion in blanket peat bogs in the Pennines. Trans. Inst. Br. Geogr. 29, 17-30.

Boyer, E.W., Hornberger, G.M., Bencala, K.E., McKnight, D.M., 1997. Response characteristics of DOC flushing in an alpine catchment. Hydrol. Process. 11 (12), 1635-1647.

Castellano, M.J., Lewis, D.B., Kaye, J.P., 2013. Response of soil nitrogen retention to the interactive effects of soil texture, hydrology, and organic matter. J. Geophys. Res. Biogeosci. 118 (1), 280-290.

Chapman, P.J., Palmer, S.M., Irvine, B.J., Mitchell, G., McDonald, A.T.A., 2012. A response to 'Changes in water colour between 1986 and 2006 in the headwaters of the River Nidd, Yorkshire, UK: a critique of methodological approaches and measurement of burning management' by Yallop et al. Biogeochemistry 111 (13), 105-109.

Chatfield, C., Collins, A.J., 1980. Introduction to Multivariate Analysis. Chapman and Hall, London, p. 246.

Clark, J.M., Ashley, D., Wagner, M., Chapman, P.J., Lane, S.N., Evans, C.D., Heathwaite, A.L. 2009. Increased temperature sensitivity of net DOC production from ombrotrophic peat due to water table draw-down. Glob. Change Biol. 15 (4), $794-807$.

Clark, J.M., Bottrell, S.H., Evans, C.D., Monteith, D.T., Bartlett, R., Rose, R., Newton, R. J., Chapman, P.J., 2010a. The importance of the relationship between scale and process in understanding long-term DOC dynamics. Sci. Total Environ. 408 (13), $2768-2775$.
Clark, J.M., Chapman, P.J., Adamson, J.K., Lane, S.N., 2005. Influence of droughtinduced acidification on the mobility of dissolved organic carbon in peat soils. Glob. Change Biol. 11 (5), 791-809.

Clark, J.M., Gallego-Sala, A.V., Allott, T.E.H., Chapman, S.J., Farewell, T., Freeman, C. House, J.I., Orr, H.G., Prentice, I.C., Smith, P., 2010b. Assessing the vulnerability of blanket peat to climate change using an ensemble of statistical bioclimatic envelope models. Clim. Res. 45 (1), 131-150.

Clark, J.M., Lane, S.N., Chapman, P.J., Adamson, J.K., 2008. Link between DOC in near surface peat and stream water in an upland catchment. Sci. Total Environ. 404 (2-3), 308-315.

Clay, G.D., Dixon, S., Evans, M.G., Rowson, J.G., Worrall, F., 2012. Carbon dioxide fluxes and DOC concentrations of eroding blanket peat gullies. Earth Surf. Proc. Land. 37 (5), 562-571.

Clay, G.D., Worrall, F., Fraser, E.D.G., 2009. Effects of managed burning upon dissolved organic carbon (DOC) in soil water and runoff water following a managed burn of a UK blanket bog. J. Hydrol. 367 (1-2), 41-51.

Clutterbuck, B., Yallop, A.R., 2010. Land management as a factor controlling dissolved organic carbon release from upland peat soils 2 Changes in DOC productivity over four decades. Sci. Total Environ. 408 (24), 6179-6191.

Cory, N., Laudon, H., Koehler, S., Seibert, J., Bishop, K., 2007. Evolution of soil solution aluminum during transport along a forested boreal hillslope. J. Geophys. Res. Biogeosci. 112 (G3)

Coulson, J.P., Bottrell, S.H., Lee, J.A., 2005. Recreating atmospheric sulphur deposition histories from peat stratigraphy: diagenetic conditions required for signal preservation and reconstruction of past sulphur deposition in the Derbyshire Peak District, UK. Chem. Geol. 218 (3-4), 223-248.

Creed, I.F., Webster, K.L., Braun, G.L., Bourbonniere, R.A., Beall, F.D., 2013. Topographically regulated traps of dissolved organic carbon create hotspots of soil carbon dioxide efflux in forests. Biogeochemistry 112 (1-3), 149-164.

Daniels, S.M., Evans, M.G., Agnew, C.T., Allott, T.E.H., 2008. Sulphur leaching from headwater catchments in an eroded peatland, South Pennines, U.K. Sci. Total Environ. 407 (1), 481-496.

DEFRA, 2013. UKEAP River Etherow 2010-2012 Precipitation Water Chemistry. (C) Crown 2013 Copyright Defra via uk-air.defra.gov.uk, Licenced Under the <http://www.nationalarchives.gov.uk/doc/open-government-licence/version/ $2 />$.

Dinsmore, K.J., Billett, M.F., Dyson, K.E., 2013. Temperature and precipitation drive temporal variability in aquatic carbon and GHG concentrations and fluxes in a peatland catchment. Glob. Change Biol. 19 (7), 2133-2148.

Dinsmore, K.J., Billett, M.F., Skiba, U.M., Rees, R.M., Drewer, J., Helfter, C., 2010. Role of the aquatic pathway in the carbon and greenhouse gas budgets of a peatland catchment. Glob. Change Biol. 16 (10), 2750-2762.

Evans, C.D., Jones, T.G., Burden, A., Ostle, N., Zieliński, P., Cooper, M.D.A., Peacock, M., Clark, J.M., Oulehle, F., Cooper, D., Freeman, C., 2012. Acidity controls on dissolved organic carbon mobility in organic soils. Glob. Change Biol. 18 (11), 3317-3331.

Evans, M.G., Allott, T.E.H., Holden, J., Flitcroft, C., Bonn, A. (Eds.). 2005 Understanding Gully Blocking in Deep Peat: Moors for the Future Report No 4

Fenner, N., Freeman, C., 2011. Drought-induced carbon loss in peatlands. Nat. Geosci. 4 (12), 895-900.

Freeman, C., Evans, C.D., Monteith, D.T., Reynolds, B., Fenner, N., 2001a. Export of organic carbon from peat soils. Nature 412 (6849), 785.

Freeman, C., Ostle, N., Kang, H., 2001b. An enzymic 'latch' on a global carbon store a shortage of oxygen locks up carbon in peatlands by restraining a single enzyme. Nature 409 (6817), 149.

Gazovic, M., Forbrich, I., Jager, D.F., Kutzbach, L., Wille, C., Wilmking, M., 2013. Hydrology-driven ecosystem respiration determines the carbon balance of a boreal peatland. Sci. Total Environ. 463-464, 675-682.

Gibson, H.S., Worrall, F., Burt, T.P., Adamson, J.K., 2009. DOC budgets of drained peat catchments: implications for DOC production in peat soils. Hydrol. Process. 23 (13), 1901-1911.

Glatzel, S., Kalbitz, K., Dalva, M., Moore, T., 2003. Dissolved organic matter properties and their relationship to carbon dioxide efflux from restored peat bogs. Geoderma 113 (3-4), 397-411.

Heppell, C.M., Worrall, F., Burt, T.P., Williams, R.J., 2002. Styles of macropore flow: implications for pollutant transport. Hydrol. Process. 16, 27-46.

Hinton, M.J., Schiff, S.L., English, M.C., 1998. Sources and flowpaths of dissolved organic carbon during storms in two forested watersheds of the Precambrian Shield. Biogeochemistry 41 (2), 175-197.

Holden, J., 2005a. Controls of soil pipe frequency in upland blanket peat. J. Geophys. Res. Earth Surf. 110 (F1), 11.

Holden, J., 2005b. Peatland hydrology and carbon release: why small-scale process matters. Philos. Transact. Roy. Soc. Math. Phys. Eng. Sci. 363 (1837), 2891-2913.

Holden, J., 2009. Topographic controls upon soil macropore flow. Earth Surf. Proc. Land. 34 (3) 345-351.

Holden, J., Burt, T.P., 2003. Hydrological studies on blanket peat: the significance of the acrotelm-catotelm model. J. Ecol. 91 (1), 86-102.

Holden, J., Smart, R.P., Dinsmore, K.J., Baird, A.J., Billett, M.F., Chapman, P.J., 2012. Natural pipes in blanket peatlands: major point sources for the release of carbon to the aquatic system. Glob. Change Biol. 18 (12), 3568-3580.

Höll, B.S., Fielder, S., Jungkunst, H.F., Kalbitz, K., Freibauer, A., Drosler, M., Stahr, K. 2009. Characteristics of dissolved organic matter following 20 years of peatland restoration. Sci. Total Environ. 408 (1), 78-83.

Joosten, $\mathrm{H} ., 2009$. The Global Peatland $\mathrm{CO}_{2}$ Picture: Peatland status and drainage related emissions in all countries of the world. UN-FCCC. Wetlands International, Ede, Copenhagen, pp. 36. 
Koehler, A.K., Sottocornola, M., Kiely, G., 2011. How strong is the current carbon sequestration of an Atlantic blanket bog? Glob. Change Biol. 17 (1), 309-319.

Laudon, H., Berggren, M., Agren, A., Buffam, I., Bishop, K., Grabs, T., Jansson, M., Kohler, S., 2011. Patterns and dynamics of dissolved organic carbon (DOC) in boreal streams: the role of processes, connectivity, and scaling. Ecosystems 14 (6), 880-893.

Limpens, J., Berendse, F., Blodau, C., Canadell, J.G., Freeman, C., Holden, J., Roulet, N. Rydin, H., Schaepman-Strub, G., 2008. Peatlands and the carbon cycle: from local processes to global implications - a synthesis. Biogeosciences 5 (5), 1475-1491.

Lindsay, J.B., 2005. The terrain analysis system: a toot for hydro-geomorphic applications. Hydrol. Process. 19 (5), 1123-1130.

Lindsay, J.B., Creed, I.F., 2005. Removal of artifact depressions from digital elevation models: towards a minimum impact approach. Hydrol. Process. 19 (16), 3113 3126.

Lindsay, R.A., 1995. Bogs: the Ecology, Classification and Conservation of Ombrotrophic Mires. Scottish Natural Heritage, Perth.

McGlynn, B.L., McDonnell, J.J., 2003. Quantifying the relative contributions of riparian and hillslope zones to catchment runoff. Water Resour. Res. 39 (11), 20.

Mei, Y., Hornberger, G.M., Kaplan, L.A., Newbold, J.D., Aufdenkampe, A.K., 2012 Estimation of dissolved organic carbon contribution from hillslope soils to a headwater stream. Water Resour. Res. 48, 17.

Mitchell, G., McDonald, A.T., 1995. Catchment characterization as a tool for upland water quality management. J. Environ. Manage. 44 (1), 83-95.

Montanarella, L., Jones, R.J.A., Hiederer, R., 2006. The distribution of peatland in Europe. Mires Peat 11.

Monteith, D.T., Stoddard, J.L., Evans, C.D., de Wit, H.A., Forsius, M., Høgåsen, T Wilander, A., Skjelkvåle, B.L., Jeffries, D.S., Vuorenmaa, J., Keller, B., Kopácek, J. Vesely, J., 2007. Dissolved organic carbon trends resulting from changes in atmospheric deposition chemistry. Nature 450 (7169), 537-U9.

Morel, B., Durand, P., Jaffrezic, A., Gruau, G., Molenat, J., 2009. Sources of dissolved organic carbon during stormflow in a headwater agricultural catchment. Hydrol. Process. 23 (20), 2888-2901.

Nilsson, M., Sagerfors, J., Buffam, I., Laudon, H., Eriksson, T., Grelle, A., Klemedtsson, L., Weslein, P., Lindroth, A., 2008. Contemporary carbon accumulation in boreal oligotrophic minerogenic mire - a significant sink after accounting for all C-fluxes. Glob. Change Biol. 14 (10), 2317-2332.

Olejnik, S., Algina, J., 2003. Generalized eta and omega squared statistics: measures of effect size for some common research designs. Psychol. Methods 8 (4), 434-447.

Parry, L.E., Chapman, P.J., Palmer, S.M., Wallage, Z.E., Wynne, H., Holden, J., 2015 The influence of slope and peatland vegetation type on riverine dissolved organic carbon and water colour at different scales. Sci. Total Environ. 527-528, 530-539.

Pastor, J., Solin, J., Bridgham, S.D., Updegraff, K., Harth, C., Weishampel, P., Dewey, B., 2003. Global warming and the export of dissolved organic carbon from borea peatlands. Oikos 100 (2), 380-386.

Roulet, N.T., Lafleur, P.M., Richard, P.J.H., Moore, T.R., Humphreys, E.R., Bubier, J., 2007. Contemporary carbon balance and late Holocene carbon accumulation in a northern peatland. Glob. Change Biol. 13 (2), 397-411.
Scott, M.J., Jones, M.N., Woof, C., Tipping, E., 1998. Concentrations and fluxes of dissolved organic carbon in drainage water from an upland peat system. Environ. Int. 24 (5-6), 537-546.

Strohmeier, S., Knorr, K.H., Reichert, M., Frei, S., Fleckenstein, J.H., Peiffer, S., Matzner, E., 2013. Concentrations and fluxes of dissolved organic carbon in runoff from a forested catchment: insights from high frequency measurements. Biogeosciences 10 (2), 905-916.

Stutter, M.I., Dunn, S.M., Lumsdon, D.G., 2012. Dissolved organic carbon dynamics in a UK podzolic moorland catchment: linking storm hydrochemistry, flow path analysis and sorption experiments. Biogeosciences 9 (6), 2159-2175.

Tallis, J.H., 1973. Studies on southern Pennine peats V. Direct observations on peat erosion and peat hydrology at Featherbed Moss. J. Ecol. 61 (1), 1-22.

Thurman, E.M., 1985. Organic geochemistry of natural waters. Developments in biogeochemistry. In: Nijhoff, M. (Ed.), Distributors for the U.S. and Canada, vol. xii. Kluwer Academic, Dordrecht (Boston Hingham, MA, USA, 497 p).

Turner, E.K., Worrall, F., Burt, T.P., 2013. The effect of drain blocking on the dissolved organic carbon (DOC) budget of an upland peat catchment in the UK. J. Hydrol. 479, 169-179.

Wallage, Z.E., Holden, J., 2010. Spatial and temporal variability in the relationship between water colour and dissolved organic carbon in blanket peat pore waters. Sci. Total Environ. 408 (24), 6235-6242.

Wallage, Z.E., Holden, J., McDonald, A.T., 2006. Drain blocking: an effective treatment for reducing dissolved organic carbon loss and water discolouration in a drained peatland. Sci. Total Environ. 367 (2-3), 811-821.

Worrall, F., Burt, T., Adamson, J., 2005. Fluxes of dissolved carbon dioxide and inorganic carbon from an upland peat catchment: implications for soil respiration. Biogeochemistry 73 (3), 515-539.

Worrall, F., Burt, T.P., Adamson, J., 2006. The rate of and controls upon DOC loss in a peat catchment. J. Hydrol. 321 (1-4), 311-325.

Worrall, F., Burt, T.P., Rowson, J.G., Warburton, J., Adamson, J.K., 2009a. The multiannual carbon budget of a peat-covered catchment. Sci. Total Environ. 407 (13), 4084-4094.

Worrall, F., Davies, H., Bhogal, A., Lilly, A., Evans, M., Turner, K., Burt, T., Barraclough, D., Smith, P., Merrington, G., 2012. The flux of DOC from the UK - predicting the role of soils, land use and net watershed losses. J. Hydrol. 448, 149-160.

Worrall, F., Evans, M.G., Bonn, A., Reed, M.S., Chapman, D., Holden, J., 2009b. Can carbon offsetting pay for upland ecological restoration? Sci. Total Environ. 408 (1), 26-36.

Worrall, F., Harriman, R., Evans, C.D., Watts, C.D., Adamson, J., Neal, C., Tipping, E., Burt, T. Grieve, I., Monteith, D., Naden, P.S., Nisbet, T., Reynolds, B., Stevens, P., 2004. Trends in dissolved organic carbon in UK rivers and lakes. Biogeochemistry 70 (3), 369-402.

Worrall, F., Reed, M.S., Warburton, J., Burt, T., 2003. Carbon budget for a British upland peat catchment. Sci. Total Environ. 312 (1-3), 133-146.

Yallop, A.R., Clutterbuck, B., 2009. Land management as a factor controlling dissolved organic carbon release from upland peat soils 1: spatial variation in DOC productivity. Sci. Total Environ. 407 (12), 3803-3813. 